\title{
Comparison of Dietary Intakes and Quality of Professional and Amateur Young Football Players
}

\section{Beril Köse $^{1 *}$, Esen Yeşil ${ }^{1}$, Merve Özdemir ${ }^{1}$ and Aysu Ayhan ${ }^{2}$}

${ }^{1}$ Department of Nutrition and Dietetics, Başkent University Faculty of Health

Sciences, Ankara, Turkey

'İncek Physical Therapy and Rehabilitation Hospital, Ankara, Turkey

*Corresponding Author: Beril Köse, Department of Nutrition and Dietetics,

Başkent University Faculty of Health Sciences, Ankara, Turkey.
Received: August 17, 2021

Published: September 25, 2021

(C) All rights are reserved by Beril Köse., et

al.

\begin{abstract}
Introduction: Nutritional requirements are higher in adolescence than in other life phases. These requirements are necessary not only for maintaining health and supporting growth and development, but also for providing energy for physical activities. In this case, the need for adequate energy and nutrient intakes becomes especially important for young athletes.

Methods: The population of this study consists of 185 amateur and professional football players whom aged 13-17 years. A questionnaire with multiple-choice and open-ended questions and the Mediterranean Diet Quality Index (KIDMED) with questions on nutritional status of adolescents were administered. In addition, a food consumption record for 24 hours was obtained.

Results: The mean KIDMED score of amateur and professional football players was $6.9 \pm 2.26$. Accordingly, 9.8\% of the amateur football players and $8.6 \%$ of the professional football players had low diet quality. The professional football players (1934.4 \pm 611.08 $\mathrm{kcal})$ had higher daily energy intake than the amateurs (1475.1 $\pm 538.60 \mathrm{kcal})$. A negative correlation was found between the KIDMED scores and body weight values of all footballers, and a positive correlation between their KIDMED scores and weekly training days.

Conclusions: The football players who participated in this study had low energy intake. Professional subjects had higher intakes of energy and macro and micro nutrients than amateurs. Both groups had similar diet quality.
\end{abstract}

Keywords: Nutrition; Health; Exercise; Diet Quality

\section{Introduction}

Nutritional requirements are higher in adolescence than in other life phases as bodily changes occurring during this period increase physical energy needs. These requirements are necessary not only for maintaining health and supporting growth and development, but also for providing energy for physical activities [1,2]. In this case, the need for adequate energy and nutrient intakes becomes especially important for young athletes [3]. In young athletes, it is difficult to make general recommendations for nutritional needs as their energy needs change significantly depending on age, growth and development levels [4].
If young athletes learn when and how to choose and consume right foods in line with their training programs, they can pursue these dietary behaviors in adulthood [5]. A negative energy balance caused by insufficient food intake has short- and long-term effects on growth, health, and physical performance (6). Unfortunately, malnutrition is a common problem among young athletes. Along with increasing demands and competitiveness, poor nutritional knowledge, behaviors and practices often impose several risks on athletes. Some studies suggest that athletes do not meet their nutritional needs and therefore do not reach their potential maximum performance. Young athletes should be encouraged to develop good 
eating habits at an early age. Therefore, it is important to evaluate both nutritional status and habits of young football players $[7,8]$.

In recent years, there has been a great deal of interest in identifying physical, physiological, and psychological characteristics useful for discovering talented football players [9]. Given the popularity and competitiveness of football, it is important to understand the basic needs of these athletes, develop programs to improve their dietary intakes, and increase their physical performances. It is important to provide these athletes with an appropriate nutritional counseling to ensure that they do not compromise their training or performance [10]. This is a particularly important issue for young football players, as several anthropometric changes in adolescence can affect football players' sports performance in later periods and can be decisive for their sports career [7].

Although football is currently the most popular sport in the world, there is a limited number of studies on nutritional status of football players. One study has reported that total energy intake is often insufficient in football players [7]. Today, a strong emphasis should be placed on the importance of nutrition and body composition of young athletes in order to reconsider their food intakes and dietary behaviors and to increase their training performances [11]. In this regard, this study aims to evaluate the nutritional knowledge, consumption and habits of professional and amateur young football players.

\section{Materials and Methods}

The population of this study consists of football players from a professional youth team of the Turkish Football Federation and those from an amateur youth team of the Ankara Amateur Sports Clubs Federation. The study sample consists of 185 football players from these professional and amateur youth teams. Professional and amateur football players aged between 13 and 17 years who agreed to participate in the study, have continued their training and do not have any illness, were included in the study. A written consent form was received from those included in the sample, whereby they voluntarily participated in the study.

A questionnaire with multiple-choice and open-ended questions and the Mediterranean Diet Quality Index (KIDMED) with questions on nutritional status of adolescents were administered by the researcher making face-to-face interviews with football players to determine their general knowledge on sports. KIDMED was developed by Serra-Majem., et al. [12] to evaluate the compliance with the Mediterranean diet in children and adolescents. This index includes a total of 16 questions, scoring from 0 to 12 (negative items are scored -1 point and positive ones are scored +1 point). It includes 3 different dietary quality, where a KIDMED score $\geq 8$ refers to optimal diet quality, between 4-7 to moderate diet quality (diet needs improvement), and $\leq 3$ to very low diet quality [12]. In addition, a food consumption record for 24 hours was obtained from those who participated in the study. The Nutritional Information Systems Package Program (BEBIS) was used to evaluate the footballers' intakes of energy, macro and micro nutrients and compared with Institute of Medicine recommendations [13]. Height was measured with a fixed stadiometer with $1 \mathrm{~mm}$ precision. Body weight and fat mass were measured via Bioelectric Impedance Analysis (BIA) (TANITA UM-074).

The data were evaluated using the Statistical Package for Social Sciences (SPSS) 17.0. Qualitative/categorical variables were presented in number $(\mathrm{N})$ and percentage (\%) and quantitative variables were presented using mean $(\mathrm{X})$ and standard deviation (SD). The Kolmogorov-Smirnov test was used to check the compliance of quantitative variables to normal distribution. Independent samples t-test and Mann-Whitney U test were used in comparison of the groups. A multiple regression analysis was performed to determine the predictive factors for KIDMED scores. In all statistical analyzes, $\mathrm{p}<0.05$ was considered statistically significant.

\section{Results and Discussion}

\begin{tabular}{|c|c|c|c|c|c|c|}
\hline & \multicolumn{2}{|c|}{$\begin{array}{c}\text { Amateur } \\
(\mathrm{n}=92)\end{array}$} & \multicolumn{2}{|c|}{$\begin{array}{c}\text { Professional } \\
(n=93)\end{array}$} & \multicolumn{2}{|c|}{$\begin{array}{c}\text { Total } \\
(n=185)\end{array}$} \\
\hline & \multicolumn{2}{|c|}{$X \pm S D$} & \multicolumn{2}{|c|}{$\mathrm{X} \pm \mathrm{SD}$} & \multicolumn{2}{|c|}{$X \pm S D$} \\
\hline Age (year) & \multicolumn{2}{|c|}{$14.0 \pm 1.62$} & \multicolumn{2}{|c|}{$14.8 \pm 1.35$} & \multicolumn{2}{|c|}{$14.4 \pm 1.54$} \\
\hline Height $(\mathrm{cm})$ & \multicolumn{2}{|c|}{$\begin{array}{c}166.6 \pm \\
11.99\end{array}$} & \multicolumn{2}{|c|}{$169.9 \pm 11.34$} & \multicolumn{2}{|c|}{$168.3 \pm 11.61$} \\
\hline Weight (kg) & \multicolumn{2}{|c|}{$\begin{array}{l}53.6 \pm \\
12.63 \\
\end{array}$} & \multicolumn{2}{|c|}{$59.5 \pm 11.64$} & \multicolumn{2}{|c|}{$56.6 \pm 12.45$} \\
\hline $\begin{array}{c}\text { Percentage of fat } \\
(\%)\end{array}$ & \multicolumn{2}{|c|}{$14.6 \pm 6.74$} & \multicolumn{2}{|c|}{$10.7 \pm 3.25$} & \multicolumn{2}{|c|}{$12.1 \pm 5.09$} \\
\hline Sports age (year) & \multicolumn{2}{|c|}{$3.2 \pm 1.98$} & \multicolumn{2}{|c|}{$5.0 \pm 1.43$} & \multicolumn{2}{|c|}{$4.1 \pm 1.93$} \\
\hline $\begin{array}{c}\text { Daily Training } \\
\text { Hours }\end{array}$ & \multicolumn{2}{|c|}{$1.7 \pm 0.42$} & \multicolumn{2}{|c|}{$1.8 \pm 0.28$} & \multicolumn{2}{|c|}{$1.7 \pm 0.36$} \\
\hline $\begin{array}{c}\text { Weekly Training } \\
\text { Days }\end{array}$ & \multicolumn{2}{|c|}{$3.9 \pm 1.28$} & \multicolumn{2}{|c|}{$4.3 \pm 0.89$} & \multicolumn{2}{|c|}{$4.1 \pm 1.12$} \\
\hline Category & $\mathbf{S}$ & $\%$ & $\mathbf{S}$ & $\%$ & $\mathbf{S}$ & $\%$ \\
\hline U13 & 43 & 46.7 & 20 & 21.5 & 63 & 34.1 \\
\hline U14 & 10 & 10.9 & 22 & 23.7 & 32 & 17.3 \\
\hline
\end{tabular}




\begin{tabular}{|c|c|c|c|c|c|c|}
\hline U15 & 14 & 15.2 & 21 & 22.6 & 35 & 18.9 \\
\hline U16 & 18 & 19.6 & 17 & 18.3 & 35 & 18.9 \\
\hline U17 & 7 & 7.6 & 13 & 14.0 & 20 & 10.8 \\
\hline Position \\
\hline Goalkeeper & 9 & 9.8 & 12 & 12.9 & 21 & 11.4 \\
\hline Defense & 15 & 16.3 & 16 & 17.2 & 31 & 16.8 \\
\hline Stopper & 16 & 17.4 & 15 & 16.1 & 31 & 16.8 \\
\hline Midfield & 42 & 45.7 & 46 & 49.5 & 88 & 47.6 \\
\hline Striker & 16 & 17.4 & 18 & 19.4 & 34 & 18.4 \\
\hline \multicolumn{7}{|c|}{ Living place } \\
\hline House (with family) & 92 & 100 & 76 & 81.7 & 168 & 90.8 \\
\hline House (alone) & 0 & 0 & 1 & 1.1 & 1 & 0.5 \\
\hline Facility & 0 & 0 & 12 & 12.9 & 12 & 6.5 \\
\hline Dormitory & 0 & 0 & 4 & 4.3 & 4 & 2.2 \\
\hline
\end{tabular}

Table 2 shows the distribution of KIDMED scores of amateur and professional football players. The mean KIDMED score of amateur and professional football players was $6.9 \pm 2.26(6.9 \pm$ 2.37 and $6.8 \pm 2.17$, respectively). Accordingly, 9.8\% of the amateur football players and $8.6 \%$ of the professional football players had low diet quality. The percentages of amateur and professional football players with moderate diet quality were $48.9 \%$ and $48.4 \%$, respectively. Of all football players, $42.2 \%$ had good diet quality. No statistically significant difference was found between amateur and professional football players in terms of KIDMED score assessment $(\mathrm{p}>0.05)$.

Table 1: Demographic, Anthropometric Characteristics and Training Frequencies of Amateur and Professional Young Football Players.

Table 1 presents the demographic, anthropometric characteristics and training frequencies of amateur and professional young football players who participated in the study. The mean age of amateur and professional football players was $14.0 \pm 1.62$ and 14.8 \pm 1.35 years, respectively. The mean height of amateur and professional football players was $166.6 \pm 11.99$ and $169.9 \pm 11.34 \mathrm{~cm}$, respectively. The mean body weight of amateur and professional football players was $53.6 \pm 12.63$ and $59.5 \pm 11.64 \mathrm{~kg}$. The mean body fat percentage of amateur and professional football players was $14.6 \pm 6.74$ and $10.7 \pm 3.25 \%$, respectively. Of the football players, $11.4 \%$ were goalkeepers, $16.8 \%$ were defense players, $16.8 \%$ were stoppers, $47.6 \%$ were midfield players and $18.4 \%$ were strikers. The mean sports age was $3.2 \pm 1.98$ years for amateur football players, $5.0 \pm 1.43$ years for professional football players, and $4.1 \pm$ 1.93 years for all participants. The mean daily training hours of all amateur and professional football players was $1.7 \pm 0.36$ hours $(1.7$ \pm 0.42 and $1.8 \pm 0.28$ hours, respectively). The mean weekly training days of all amateur and professional footballers was $4.1 \pm 1.12$ days ( $3.9 \pm 1.28$ and $4.3 \pm 0.89$ days, respectively).

\begin{tabular}{|c|c|c|c|c|c|c|c|}
\hline & \multicolumn{2}{|c|}{$\begin{array}{l}\text { Amateur } \\
(\mathrm{n}=92)\end{array}$} & \multicolumn{2}{|c|}{$\begin{array}{l}\text { Profession- } \\
\text { al }(n=93)\end{array}$} & \multicolumn{2}{|c|}{$\begin{array}{c}\text { Total } \\
(n=185)\end{array}$} & $\mathbf{p}$ \\
\hline KIDMED Score & \multicolumn{2}{|c|}{$X \pm S D$} & \multicolumn{2}{|c|}{$\mathrm{X} \pm \mathrm{SD}$} & \multicolumn{2}{|c|}{$X \pm S D$} & \\
\hline & \multicolumn{2}{|c|}{$6.9 \pm 2.37$} & \multicolumn{2}{|c|}{$6.8 \pm 2.17$} & \multicolumn{2}{|c|}{$6.9 \pm 2.26$} & 0.849 \\
\hline $\begin{array}{l}\text { KIDMED Clas- } \\
\text { sification }\end{array}$ & $\mathrm{n}$ & $\%$ & $\mathrm{n}$ & $\%$ & $\mathrm{n}$ & $\%$ & \\
\hline $\begin{array}{c}\text { Low Dietary } \\
\text { Quality }\end{array}$ & 9 & 9.8 & 8 & 8.6 & 17 & 9.2 & 0.771 \\
\hline $\begin{array}{l}\text { Moderate Di- } \\
\text { etary Quality }\end{array}$ & 45 & 48.9 & 45 & 48.4 & 90 & 48.6 & \\
\hline $\begin{array}{c}\text { Good Dietary } \\
\text { Quality }\end{array}$ & 38 & 41.3 & 40 & 43.0 & 78 & 42.2 & \\
\hline Total & 92 & 100.0 & 93 & 100.0 & 185 & 100.0 & \\
\hline
\end{tabular}

Table 2: Distribution of KIDMED Scores of Amateur and Professional Young Football Players.

\begin{tabular}{|c|c|c|c|c|c|}
\hline $\begin{array}{c}\text { Energy } \\
\text { and Macro } \\
\text { Nutrients }\end{array}$ & $\begin{array}{l}\text { Amateur } \\
(n=92)\end{array}$ & $\begin{array}{l}\text { Profes- } \\
\text { sional (n } \\
=93)\end{array}$ & $\begin{array}{c}\text { Total }(n= \\
185)\end{array}$ & & \\
\hline & $X \pm S D$ & $X \pm S D$ & $X \pm S D$ & RDA & $\mathbf{P}$ \\
\hline $\begin{array}{c}\text { Energy } \\
\text { (kcal) }\end{array}$ & $\begin{array}{c}1475.1 \pm \\
538.60\end{array}$ & $\begin{array}{c}1934.4 \pm \\
611.08\end{array}$ & $\begin{array}{r}1705.9 \\
\pm 619.05 \\
\end{array}$ & 2900 & $0.000^{\mathrm{a}}$ \\
\hline $\begin{array}{l}\text { Carbohy- } \\
\text { drate (g) }\end{array}$ & $\begin{array}{c}157.2 \pm \\
71.62\end{array}$ & $\begin{array}{c}206.3 \pm \\
84.99\end{array}$ & $\begin{array}{c}181.9 \pm \\
82.18\end{array}$ & 435 & $0.000^{\mathrm{a}}$ \\
\hline $\begin{array}{l}\text { Carbo- } \\
\text { hydrate } \\
\text { (TE\%) }\end{array}$ & $\begin{array}{l}42.8 \pm \\
11.11\end{array}$ & $\begin{array}{c}43.1 \pm \\
9.18\end{array}$ & $\begin{array}{l}42.9 \pm \\
10.16\end{array}$ & 60 & $0.857^{\mathrm{a}}$ \\
\hline $\begin{array}{l}\text { Carbohy- } \\
\text { drate (g/ } \\
\text { kg) }\end{array}$ & $3.3 \pm 1.61$ & $3.5 \pm 1.49$ & $3.3 \pm 1.55$ & $6-10$ & $0.160^{\mathrm{b}}$ \\
\hline Protein (g) & $\begin{array}{l}69.7 \pm \\
26.22 \\
\end{array}$ & $\begin{array}{l}87.3 \pm \\
30.28\end{array}$ & $\begin{array}{l}78.5 \pm \\
29.62 \\
\end{array}$ & $\begin{array}{l}73- \\
109 \\
\end{array}$ & $0.000^{\mathrm{a}}$ \\
\hline $\begin{array}{c}\text { Protein } \\
\text { (TE\%) }\end{array}$ & $20.1 \pm 5.56$ & $\begin{array}{c}18.7 \pm \\
3.63\end{array}$ & $\begin{array}{c}19.4 \pm \\
4.72\end{array}$ & $10-15$ & $0.135^{\mathrm{a}}$ \\
\hline $\begin{array}{c}\text { Protein (g/ } \\
\mathrm{kg})\end{array}$ & $1.4 \pm 0.55$ & $1.5 \pm 0.57$ & $1.4 \pm 0.58$ & $1.2-1.7$ & $0.306^{\mathrm{b}}$ \\
\hline Fat (g) & $\begin{array}{c}60.5 \pm \\
26.08\end{array}$ & $\begin{array}{l}81.5 \pm \\
28.25\end{array}$ & $\begin{array}{l}71.0 \pm \\
29.09\end{array}$ & $97 \downarrow$ & $0.000^{\mathrm{b}}$ \\
\hline Fat (TE\%) & $37.1 \pm 9.76$ & $\begin{array}{c}38.2 \pm \\
8.25\end{array}$ & $\begin{array}{c}37.7 \pm \\
9.03\end{array}$ & $30 \downarrow$ & $0.415^{\mathrm{b}}$ \\
\hline Fiber (g) & $13.1 \pm 9.54$ & $\begin{array}{c}17.4 \pm \\
6.76 \\
\end{array}$ & $\begin{array}{c}15.2 \pm \\
8.52 \\
\end{array}$ & $29-38$ & $0.001^{\mathrm{b}}$ \\
\hline $\begin{array}{c}\text { Cholesterol } \\
(\mathrm{mg})\end{array}$ & $\begin{array}{c}334.1 \pm \\
190.54\end{array}$ & $\begin{array}{l}448.6 \pm \\
179.53 \\
\end{array}$ & $\begin{array}{c}391.6 \pm \\
193.31\end{array}$ & $300 \downarrow$ & $0.000^{\mathrm{b}}$ \\
\hline $\begin{array}{c}\text { Saturated } \\
\text { fatty acid } \\
(\%)\end{array}$ & $22.9 \pm 9.84$ & $\begin{array}{l}31.9 \pm \\
12.34\end{array}$ & $\begin{array}{l}27.4 \pm \\
12.03\end{array}$ & $10 \downarrow$ & $0.000^{\mathrm{b}}$ \\
\hline $\begin{array}{c}\text { Vitamin A } \\
(\mathrm{mcg})\end{array}$ & $\begin{array}{l}739.6 \pm \\
449.77 \\
\end{array}$ & $\begin{array}{l}1253.1 \pm \\
2285.44\end{array}$ & $\begin{array}{c}997.8 \\
\pm 1666.72 \\
\end{array}$ & 900 & $0.000^{\mathrm{a}}$ \\
\hline $\begin{array}{c}\text { Vitamin E } \\
(\mathrm{mg})\end{array}$ & $9.6 \pm 6.95$ & $\begin{array}{c}12.2 \pm \\
7.18\end{array}$ & $\begin{array}{c}10.9 \pm \\
7.17\end{array}$ & 15 & $0.004^{\mathrm{a}}$ \\
\hline $\begin{array}{c}\text { Thiamine } \\
(\mathrm{mg})\end{array}$ & $0.6 \pm 0.30$ & $0.8 \pm 0.30$ & $0.7 \pm 0.32$ & 1.2 & $0.000^{\mathrm{b}}$ \\
\hline $\begin{array}{l}\text { Riboflavin } \\
\text { (mg) }\end{array}$ & $1.3 \pm 0.70$ & $1.6 \pm 0.69$ & $1.4 \pm 0.71$ & 1.3 & $0.003^{b}$ \\
\hline Niacin (mg) & $10.0 \pm 5.56$ & $\begin{array}{c}13.5 \pm \\
6.89 \\
\end{array}$ & $\begin{array}{c}11.8 \pm \\
6.50\end{array}$ & 16 & $0.000^{\mathrm{a}}$ \\
\hline
\end{tabular}




\begin{tabular}{|c|c|c|c|c|c|}
\hline $\begin{array}{c}\text { Folate } \\
(\mathrm{mcg})\end{array}$ & $\begin{array}{c}188.1 \pm \\
87.31\end{array}$ & $\begin{array}{c}265.1 \pm \\
89.66\end{array}$ & $\begin{array}{c}226.8 \pm \\
96.33\end{array}$ & 400 & $0.000^{\mathrm{b}}$ \\
\hline Vitamin & $7.0 \pm 11.03$ & $7.2 \pm 8.59$ & $7.1 \pm 9.86$ & 2.4 & $0.405^{\mathrm{a}}$ \\
B12 (mcg) & & & & & \\
\hline $\begin{array}{c}\text { Vitamin C } \\
(\mathrm{mg})\end{array}$ & $71.0 \pm$ & $107.0 \pm$ & $89.1 \pm$ & 90 & $0.000^{\mathrm{b}}$ \\
\hline $\begin{array}{c}\text { Vitamin B6 } \\
(\mathrm{mg})\end{array}$ & $1.1 \pm 0.53$ & $1.5 \pm 0.57$ & $1.3 \pm 0.58$ & 1.3 & $0.000^{\mathrm{b}}$ \\
\hline $\begin{array}{c}\text { Potassium } \\
(\mathrm{mg})\end{array}$ & $1801.2 \pm$ & $2458.1 \pm$ & $2131.4 \pm$ & 3000 & $0.000^{\mathrm{b}}$ \\
\hline Calcium & 631.10 & 925.48 & 937.19 & & \\
$(\mathrm{mg})$ & 356.13 & 418.78 & 402.41 & & \\
\hline Magnesium & $200.8 \pm$ & $269.8 \pm$ & $235.5 \pm$ & 420 & $0.000^{\mathrm{b}}$ \\
$(\mathrm{mg})$ & 85.65 & 92.49 & 95.40 & & \\
\hline Phosphor & $1051.0 \pm$ & $1340.3 \pm$ & $1196.4 \pm$ & 700 & $0.000^{\mathrm{b}}$ \\
$(\mathrm{mg})$ & 395.32 & 438.54 & 441.01 & & \\
\hline Iron (mg) & $8.6 \pm 4.27$ & $10.7 \pm$ & $9.6 \pm 4.15$ & 8 & $0.000^{\mathrm{b}}$ \\
\hline Zinc (mg) & $9.2 \pm 3.88$ & $11.4 \pm$ & $10.3 \pm$ & 11 & $0.000^{\mathrm{b}}$ \\
\hline & & 4.31 & 4.24 & & \\
\hline
\end{tabular}

Table 3: Daily Energy And Macro And Micro Nutrients Consumption Mean (X) And Standard Deviation Values Of Amateur And

Professional Young Football Players.

${ }^{\mathrm{a}}$ Mann-Whitney U Test, ${ }^{\mathrm{b}}$ Independent Samples t-test, RDA: Recommended Dietary Allowance [13].

Table 3 presents the football players' daily energy intakes and macro nutrient consumption amounts. Accordingly, the professional football players $(1934.4 \pm 611.08 \mathrm{kcal})$ had higher daily energy intake than the amateurs (1475.1 $\pm 538.60 \mathrm{kcal})$. Of the daily energy intakes of professional football players, $43.1 \pm 9.18 \%$ came from carbohydrates, $18.7 \pm 3.63 \%$ from proteins, and $38.2 \pm 8.25$ $\%$ from fats. Of the daily energy intakes of amateur football players, $42.8 \pm 11.11 \%$ came from carbohydrates, $20.1 \pm 5.56 \%$ from proteins, and $37.1 \pm 9.76 \%$ from fats. The daily fiber consumption of professional football players was $17.4 \pm 6.76 \mathrm{~g}$, which was higher than that of amateur ones. Likewise, the daily cholesterol intake was higher in professional football players $(448.6 \pm 179.53 \mathrm{mg})$ and this difference was statistically significant $(\mathrm{p}<0.05)$. Professional football players had higher vitamin A (1253.1 \pm 2285.44 $\mathrm{mcg})$ and vitamin $\mathrm{E}(12.2 \pm 7.18 \mathrm{mg})$ intakes than amateur ones, and a statistically significant difference was found between them $(p<0.05)$. There were significant differences between the two groups in terms of thiamine, riboflavin and niacin intakes. Folate intake was found to be $188.1 \pm 87.31 \mathrm{mcg}$ in amateur football play- ers, which was significantly lower than that of professional ones $(\mathrm{p}$ $<0.05)$. Both groups had similar vitamin $B_{12}$ intakes $(7.0 \pm 11.03$ for amateurs and $7.2 \pm 8.59$ mcg for professionals), whereby there was no statistically significant difference between them ( $p>0.05)$. Professional football players had higher vitamin $B_{6}$ and $C$ intakes than amateur ones $(\mathrm{p}<0.05)$.

In addition, potassium and magnesium intakes were statistically significantly higher in professional football players (2458.1 $\pm 925.48 \mathrm{mg}$ and $269.8 \pm 92.49 \mathrm{mg}$, respectively) ( $\mathrm{p}<0.05)$. Calcium intakes were $665.2 \pm 356.13 \mathrm{mg}$ for amateur football players and $879.3 \pm 418.78 \mathrm{mg}$ for professional ones, and this difference was statistically significant ( $p<0.05$ ). The differences between the groups' daily average intakes of phosphorus, iron and zinc minerals were also found to be statistically significant $(\mathrm{p}<0.05)$.

The results of this study are valuable because studying on adolescents is difficult and nutrition is very important in terms of their growth and development. Energy requirements are more variable in adolescent athletes, depending on age, activity level, growth rate and physical maturity stage. In this study, energy intake was found to be higher in professional adolescent athletes compared to amateurs. However, both groups had energy intakes below the RDA recommendations (<2900 kcal). This result was particularly highlighted. Similar energy intakes to the RDA recommendation were observed in studies involving athletes with similar ages to those in our study $[7,15]$.

When we examined other macronutrient intakes, the total energy percentage of protein and fat was higher than the recommended rate, while carbohydrate was low. In fact, we know that these recommendations are for individuals who are not athletes. For this reason, it is more correct to call the recommendations low or high, and actually give suggestions suitable for individual exercise levels. However, the fact that the carbohydrate percentage of total energy intake is well below $60 \%$ is not a situation we recommend especially before training. Suboptimal carbohydrate intake can cause premature muscle glycogen depletion during training and competition, as well as poor glycogen re-synthesis after exercise, resulting in poor performance. Fats are critical for the absorption of fatsoluble vitamins. Fats are also essential fuel source for athletes and necessary for growth and development in adolescents. However, it is important to keep fat intake at an optimum level, as high intakes can cause problems (such as cardiovascular diseases), especially in 
the long term. Protein is not the primary source of energy in light or short-term exercises, but proteins inhibit the reduction of blood glucose through liver gluconeogenesis as exercise duration increases. Similar to the presents study, studies have reported high protein intake among adolescents $[15,16]$. Therefore, it is not correct to recommend extra protein intake (e.g. protein powders or extracts) for them. In this study, cholesterol intakes of adolescents in parallel to their protein intakes were also found to be higher compared to the recommendations. Their dietary fiber intakes were quite low. Dietary fiber is especially important for gastrointestinal system. Therefore, athletes should be encouraged to take complex carbohydrates.

A statistically significant difference was found between the micronutrient intakes of amateur and professional footballers $(p<0.001)$. The professional football players had higher intakes of all macro and micro nutrients than amateurs. Our amateur playres had a lower intake of micro nutrients that met RDA values with regard to vitamin $A, E, C, B_{6}$, thiamine, niacin, folate, calcium, magnesium and zinc, while they had a higher intake of micro nutrients that met RDA values regarding only vitamin $\mathrm{B}_{12}$ and phosphorus. Riboflavin and iron intake were equal to RDA recommendations. Our professional players had a lower intake of micro nutrients that met RDA values with regard to vitamin $\mathrm{E}$, thiamine, niacin, folate, calcium and magnesium, while they had a higher intake of micro nutrients that met $\mathrm{RDA}$ values regarding vitamin $\mathrm{A}, \mathrm{C}, \mathrm{B}_{6}, \mathrm{~B}_{12}$, riboflavin and phosphorus and iron. Zinc were equal to RDA recommendations. Calcium requirement is particularly high during adolescence. An adequate calcium consumption is necessary for bone development in adolescents and increased bone burden in athletes, as well as in terms of possible osteoporosis risk in later years. However, as in our study, there is generally low calcium consumption in both sedentary adolescents and sports adolescents $[8,16,17]$.

\begin{tabular}{|c|c|c|c|c|c|c|c|c|c|c|c|c|c|c|c|c|c|c|c|c|c|}
\hline & \multicolumn{7}{|c|}{ Amateur $(n=92)$} & \multicolumn{7}{|c|}{ Professional $(n=93)$} & \multicolumn{7}{|c|}{ Total $(n=185)$} \\
\hline & \multicolumn{2}{|c|}{$\begin{array}{l}\text { Unstandard- } \\
\text { ized } \\
\text { Coefficient }\end{array}$} & \multirow{2}{*}{$\begin{array}{c}\text { Stan- } \\
\text { dardized } \\
\text { Coeffi- } \\
\text { cient } \\
\\
\beta\end{array}$} & \multirow[t]{2}{*}{$\mathrm{t}$} & \multirow[t]{2}{*}{$\mathrm{p}$} & \multirow[t]{2}{*}{$\mathrm{R}$} & \multirow[t]{2}{*}{$\mathrm{R}^{2}$} & \multicolumn{2}{|c|}{$\begin{array}{l}\text { Unstandard- } \\
\text { ized } \\
\text { Coefficient }\end{array}$} & \multirow{2}{*}{$\begin{array}{c}\text { Stan- } \\
\text { dard- } \\
\text { ized } \\
\text { Coef- } \\
\text { ficient } \\
\\
\beta\end{array}$} & \multirow[t]{2}{*}{$\mathrm{t}$} & \multirow[t]{2}{*}{$\mathrm{p}$} & \multirow[t]{2}{*}{$\mathrm{R}$} & \multirow[t]{2}{*}{$\mathrm{R}^{2}$} & \multicolumn{2}{|c|}{$\begin{array}{l}\text { Unstandard- } \\
\text { ized } \\
\text { Coefficient }\end{array}$} & \multirow{2}{*}{$\begin{array}{c}\begin{array}{c}\text { Stan- } \\
\text { dardized } \\
\text { Coeffi- } \\
\text { cient }\end{array} \\
\beta\end{array}$} & \multirow[t]{2}{*}{$\mathrm{t}$} & \multirow[t]{2}{*}{$\mathrm{p}$} & \multirow[t]{2}{*}{$\mathrm{R}$} & \multirow[t]{2}{*}{$\mathrm{R}^{\mathrm{E}}$} \\
\hline & B & $\mathrm{SE}$ & & & & & & $\mathrm{B}$ & SE & & & & & & $\beta$ & SE & & & & & \\
\hline $\begin{array}{c}\text { Age } \\
\text { (year) }\end{array}$ & 0.135 & 0.251 & 0.096 & 0.538 & 0.592 & 0.318 & 0.101 & -0.158 & 0.287 & -0.101 & -0.550 & 0.584 & 0.255 & 0.065 & 0.014 & 0.182 & 0.079 & 0.079 & 0.937 & 0.265 & 0.070 \\
\hline $\begin{array}{c}\text { Weight } \\
(\mathrm{kg})\end{array}$ & -0.061 & 0.032 & -0.334 & -1.943 & $0.048^{*}$ & & & -0.034 & 0.030 & -0.188 & -1.145 & 0.256 & & & -0.049 & 0.021 & -2.311 & -2.311 & $0.022^{*}$ & & \\
\hline $\begin{array}{l}\text { Sports } \\
\text { age } \\
\text { (year) }\end{array}$ & 0.191 & 0.132 & 0.169 & 1.442 & 0.153 & & & 0.221 & 0.183 & 0.146 & 1.210 & 0.230 & & & -0.124 & 0.214 & -0.580 & 1.235 & 0.219 & & \\
\hline $\begin{array}{c}\text { Weekly } \\
\text { Train- } \\
\text { ing } \\
\text { Hours }\end{array}$ & 0.204 & 0.133 & 0.223 & 1.530 & 0.130 & & & 0.227 & 0.191 & 0.208 & 1.191 & 0.237 & & & 0.206 & 0.107 & 1.923 & -0.580 & 0.563 & & \\
\hline $\begin{array}{c}\text { Weekly } \\
\text { Train- } \\
\text { ing } \\
\text { Days }\end{array}$ & -0.080 & 0.256 & -0.044 & -0.311 & 0.756 & & & -0.100 & 0.418 & -0.041 & -0.238 & 0.812 & & & 0.118 & 0.096 & 1.235 & 1.973 & $0.046^{*}$ & & \\
\hline
\end{tabular}

Table 4: The Relationship Between Some Risk Factors And Kidmed Scores Of Amateur And Professional Young Football Players.

According to the results of multiple regression analysis, a negative correlation was found between the KIDMED scores and body weight values of amateur football players. A negative correlation was also found between the KIDMED scores and body weight values of all footballers, and a positive correlation between their KIDMED scores and weekly training days $(\mathrm{p}<0.05)$.
Optimal fat percentage for adolescent athletes can be an advantage to performance. Professional athletes have lower percentage of fat compared to amateurs. According to the results of this study, as body weight increased in amateurs and all athletes, their KIDMED scores decreased, indicating the effect of body weight on diet quality. For all athletes, as weekly training days increased, their KIDMED scores increased, suggesting a 
higher dietary quality in athletes who train more. Both groups had similar KIDMED scores. The number of athletes with good dietary quality was found to be higher in the present study compared to those on sedentary adolescents $[18,19]$. This may be because athletes may have more information about nutrition.

\section{Conclusion}

In conclusion, all the football players who participated in this study had low energy intake. Professional subjects had higher intakes of energy and macro and micro nutrients than amateurs. Both groups had similar diet quality.

\section{Conflict of Interest}

No financial interest or any conflict of interest exists.

\section{Bibliography}

1. Hosseinzadeh J., et al. "Evaluation of Dietary Intakes, Body Composition, and Cardiometabolic Parameters in Adolescent Team Sports Elite Athletes: A Cross-sectional Study". Advanced Biomedical Research (2017).

2. De Sousa EF., et al. "Assessment of nutrient and water intake among adolescents from sports federations in the Federal District, Brazil". British Journal of Nutrition 99 (2008): 1275-1283.

3. Croll JK., et al. "Adolescents Involved in Weight-Related and Power Team Sports Have Better Eating Patterns and Nutrient Intakes than Non Sport-Involved Adolescents". Journal of the American Dietetıc Associatıon 106 (2006): 709-717.

4. Hoch AZ and Goossen K. "Nutritional Requirements of the Child and Teenage Athlete". Physical Medicine and Rehabilitation Clinics of North America 19 (2008): 373-398.

5. Manore MM., et al. "Sport Nutrition Knowledge, Behaviors and Beliefs of High School Soccer Players". Nutrients 9 (2017): 350.

6. Juzwiak CR., et al. "Body composition and nutritional profile of male adolescent tennis players". Journal of Sports Sciences 26.11 (2008): 1209-1217.

7. Hidalgo y Teran Elizondo R., et al. "Nutritional intake and nutritional status in elite Mexican teenagers soccer players of different ages". Nutricion Hospitalaria 32.4 (2015): 1735-1743.

8. Papadopoulou SK., et al. "Macro- and micro-nutrient intake of adolescent Greek female volleyball players". International Journal of Sport Nutrition and Exercise Nutrient Metabolism 12.1 (2002): 73-80.
9. Iglesias-Gutiérrez E., et al. "Food habits and nutritional status assessment of adolescent soccer players. A necessary and accurate approach". Canadian Journal of Applied Physiology 30.1 (2005): 18-32.

10. Jonnalagadda SS., et al. "Dietary Practices, Attitudes, and Physiological Status of Collegiate Freshman Football Players". Journal of Strength and Conditioning Research 15.4 (2001): 507-513.

11. Daneshvar P., et al. "Dietary behaviors and nutritional assessment of young male isfahani wrestlers". International Journal of Preventive Medicine 4.1 (2013): 48-52.

12. Serra-Majem L., et al. "Food, youth and the Mediterranean diet in Spain. Development of KIDMED, Mediterranean Diet Quality Index in children and adolescents". Public Health Nutrition 7.7 (2004): 931-935.

13. Institue of Medicine. Dietary references intakes. Washington DC, National Academies Pres (2005).

14. Bettonviel A EO., et al. "Nutritional Status and Daytime Pattern of Protein Intake on Match, Post-Match, Rest and Training Days in Senior Professional and Youth Elite Soccer Players". International Journal of Sport Nutrition and Exercise Metabolism 26.3 (2016): 285-293.

15. Daneshvar P., et al. "Dietary behaviors and nutritional assessment of young male isfahani wrestlers". International Journal of Preventive Medicine 4 (2013): S48-52.

16. Juzwiak CR., et al. "Body composition and nutritional profile of male adolescent tennis players". Journal of Sports Science 26.11 (2008): 1209-1217.

17. de Assumpção D., et al. "Calcium intake by adolescents: a population-based health survey". Journal of Pediatrics (Rio J). 92.3 (2016): 251-259.

18. Papadaki S and Mavrikaki E. "Greek adolescents and the Mediterranean diet: factors affecting quality and adherence". Nutrition 31.2 (2015): 345-349.

19. Mazaraki A., et al. "Adherence to the Mediterranean diet and albuminuria levels in Greek adolescents: data from the Leontio Lyceum ALbuminuria (3L study)". European Journal of Clinical Nutrition 35.2 (2011): 219-225.

\section{Volume 5 Issue 10 October 2021 (c) All rights are reserved by Ravi Kant Upadhyay.}

